\title{
Pengaruh Komitmen Organisasi Terhadap Kinerja Perawat di RS PKU Muhammadiyah Bantul
}

\section{The Influence of Organizational Commitment towards Nurse Performances in PKU Muhammadiyah Hospital Bantul}

\author{
Sumarni ${ }^{1}$ Andri Pramuntadi ${ }^{2}$ \\ ${ }^{12}$ Administrasi Rumah Sakit Fakultas Ilmu-Ilmu Kesehatan Universitas Alma Ata \\ Email: arniandigali@gmail.com, andri.pramuntadi@gmail.com
}

\begin{abstract}
ABSTRAK
Komitmen organisasi merupakan komponen penting dalam keberhasilan kinerja organisasi, karena unsur pendorong bagi seseorang untuk melakukan pekerjaan sendiri maupun kelompok. Tujuan Penelitian ini untuk menganalisis pengaruh komitmen organisasi terhadap kinerja perawat di RS PKU Muhammadiyah Bantul. Penelitian ini menggunakan desain penelitian pendekatan kuantitatif dengan rancangan cross sectional study. Jumlah Sampel penelitian adalah perawat bagian rawat inap di RS PKU Muhammadiyah Bantul sebanyak 150 orang, yang dipilih menggunakan metode survey. Pengumpulan data dilakukan menggunakan kuesioner terkait variabel komitmen organisasi dan kinerja perawat. Hasil penelitian menunjukan bahwa ada hubungan positif antara iklim organisasi dengan komitmen profesi $(p=0,001, r=0,326)$, sehingga hipotesis dalam penelitian ini diterima. Hal ini membuktikan bahwa iklim organisasi dapat berpengaruh terhadap perilaku individu yang berdampak terhadap komitmen profesinya. Ada pengaruh positif variabel komitmen organisasi terhadap kinerja perawat di RS PKU Muhammadiyah Bantul, koefisien determinansi $\left(r^{2}=0,1063\right)$. Dengan demikian hasil penelitian ini menunjukkan bahwa semakin positif iklim organisasi maka semakin tinggi komitmen profesi, begitu juga apabila semakin negatif iklim organisasi maka semakin rendah pula komitmen profesi.
\end{abstract}

Kata kunci: Komitmen organisasi, Kinerja, Perawat

\section{ABSTRACT}

Organizational commitment is an important component in succeeding the organizational performance, acting as one motivating element for the individual to accomplish their work independently or in a group. The purpose of this research is to analyze the influence of organizational commitment towards nurse performances in PKU Muhammadiyah Hospital Bantul. This research uses a quantitative research approach designed with cross sectional study. The number of sample is about 150 nurses of the inpatients in PKU Muhammadiyah Hospital Bantul, selected through a survey method. The data are collected by using a questionnaire related to the variable of both organizational commitment and nurse performance. The result shows that there is a positive relationship between organizational climate and professional commitment ( $p=0.001, r=0.326)$, making the hypothesis of this research acceptable. This result proves that organizational climate is able to affect the individual behavior that resulting in their professional commitment. There is a positive influence of organizational commitment towards the performance of the nurses in PKU Muhammadiyah Hospital Bantul, with coefficient of determination $(r 2=0.1063)$. Thus, the results of this research indicate that the more positive the organizational climate, the higher the professional commitment, as well as the more negative the organizational climate, the lower the professional commitment.

Keywords: Organizational Commitment, Performance, Nurses 


\section{PENDAHULUAN}

Tekanan globalisasi dibidang kesehatan berakibat timbulnya persaingan antar rumah sakit baik pemerintah, swasta dan asing. Masyarakat menuntut rumah sakit memberikan pelayanan dengan konsep one step quality services yang berarti seluruh kebutuhan pelayanan kesehatan dan pelayanan terkait dengan kebutuhan rumah sakit harus dilayani rumah sakit secara mudah, cepat, akurat dan bermutu, untuk memenuhi kebutuhan globalisasi maka tenaga kesehatan harus mampu menjadi tenaga yang siap memberikan pelayanan yang memuaskan pelanggan, mengembangkan kemampuan-kemampuan baru, produk inovatif, memiliki komitmen dan mampu mengelola perubahan melalui kerja sama kelompok, dan dituntut untuk berfikir global serta memiliki visi (Nawawi, 2011) .

Ketika rumah sakit menawarkan pekerjaan dan pelamar kerja menerima tawaran tersebut, pelamar kerja tersebut telah menjadi bagian dari rumah sakit. Dengan menjadi bagian dari rumah sakit, karyawan dididik untuk berkomitmen pada tujuan rumah sakit. Ada banyak alasan mengapa sebuah organisasi harus berusaha meningkatkan komitmen organisasi para karyawannya. Sebagai contoh banyak penelitian menemukan bahwa semakin karyawan berkomitmen kepada perusahaan, karyawan tersebut akan berusaha lebih baik dalam menyelesaikan tugas-tugasnya. Selain itu, karyawan yang berkomitmen juga akan meningkatkan produktivitas para karyawan karena karyawan merasa menyatu dengan perusahaan dan bekerja untuk mencapai tujuan perusahaan. Dengan adanya rasa menyatu dengan perusahaan, karyawan tidak berpikir untuk meninggalkan perusahaan sehingga dikatakan komitmen organisasi yang tinggi akan menurunkan keinginan untuk pindah para karyawan (Yani, 2012).

Pembinaan sumber daya tenaga kesehatan merupakan salah satu faktor yang harus ditingkatkan. Memperhatikan sumber daya manusia secara individu sama pentingnya dengan faktor fisik, sebagai contoh, pegawai yang merasa tertekan oleh kerja adalah orang-orang yang tidak puas, menifestasi fisik yang timbul dapat berupa penyakit-penyakit fisik serta perilaku dapat mengakibatkan perilaku yang tidak terkendali, pengunduran diri, kelambanan dan komitmen kerja yang rendah dan pada akhirnya akan menjadi frustasi. Pembinaan sumber daya 
tenaga kesehatan juga harus diimbangi dengan komitmen organisasi (Mangkuprawira, 2011).

Sumber Daya Manusia (SDM) merupakan faktor penentu yang sangat penting bagi keefektifan berjalannya sebuah kegiatan dalam suatu organisasi. Keberhasilan dan kinerja seseorang dalam suatu bidang pekerjaan banyak ditentukan oleh tingkat kompetensi, profesionalisme, dan juga komitmennya terhadap bidang pekerjaan yang ditekuninya itu. Saat ini, banyak isu-isu mengenai tingkat perpindahan kerja yang dilakukan oleh para karyawan (Sidharta \& Margaretha, 2011).

Faktor penentu keberhasilan organisasi pelayanan kesehatan saat ini terletak pada seberapa baiknya manajemen membangun komitmen terutama kinerja karyawan sebagai pelanggan internal. Seberapa baik para eksekutif dan semua karyawan pada semua lapisan menekankan pentingnya patient retention. Seberapa baik komitmen pelanggan diterjemahkan kedalam aksi, proses dan berbagai catatan kinerja yang mudah dimengerti serta seberapa serius kepemimpinan melihat semua karyawan sebagai investasi yang bernilai dan bukannya beban bagi organisasi. Dalam situasi ini dibutuhkan dukungan dari para pemimpin untuk menggalang komitmen dari semua pihak (Muchlas, 2012).

Komitmen individu pada organisasi adalah lebih dari sekedar suatu tahap loyal terhadap organisasi tempatnya bekerja yang mana anggota-anggota organisasi mengekspresikan kepeduliannya pada kesuksesan dan kesejahteraan organisasi. Komitmen organisasi adalah manifestasi sehari-hari atas nilai dan tradisi yang ada dalam organisasi. Hal tersebut tampak dari perilaku karyawan, harapan mereka terhadap organisasi dan rekan kerja, serta keadaan yang dikatakan normal yang ditunjukkan oleh karyawan saat melakukan tugas mereka, manifestasi dalam kegiatan. Komitmen organisasi merupakan komponen penting dalam keberhasilan kinerja organisasi, karena unsur pendorong bagi seseorang untuk melakukan pekerjaan sendiri maupun kelompok (Sunyoto, 2011).

Ketangguhan suatu organisasi baik itu pemerintah, bisnis maupun masyarakat dapat ditelusuri dan bermuara pada kepemimpinan yang mampu memberikan komitmen yang benar dan menarik dalam keikutsertaan karyawan dalam 
pengambilan keputusan sehingga memiliki pondasi yang kuat seperti rasa ikut memiliki, rasa tanggung jawab dalam organisasi (Sutrisno, 2010). Apabila komitmen atasan/bawahan tinggi terhadap pemikiran konsep dan gagasan maka akan mendatangkan hasil yang optimal bagi organisasi. Pada masa desentralisasi dimana setiap orang dituntut proaktif menumbuh kembangkan organisasinya dibutuhkan suatu komitmen yang tinggi dari setiap anggota organisasni. Kinerja dipengaruhi oleh dua hal utama yaitu faktor organisasional yang meliputi komitmen organisasi, sistem imblan jasa (gaji, bonus dan promosi), kualitas pengawasan, beban kerja, minat dan lingkungan kerja serta faktor personal yang meliputi ciri kepribadian, senioritas, masa kerja dan kemampuan (Azizah, 2012).

Komitmen organisasi mencerminkan tingkatan di mana seseorang mengenal perusahaan dan tujuan-tujuannya. Pemahaman umum menyatakan bahwa komitmen adalah sebuah persetujuan untuk melakukan sesuatu untuk diri sendiri, orang lain, kelompok atau organisasi. Komitmen organisasi terdiri dari tiga komponen yang saling berhubungan, yakni: komitmen afektif, komitmen normatif dan komitmen berkelanjutan (Kreitner, Robert; Kinicki, 2014).

RS PKU Muhammadiyah Bantul merupakan salah satu rumah sakit terbesar di Daerah Bantul Yogyakarta, di mana dalam pengelolaannya perlu memperhatikan pentingnya isu-isu dalam organisasi, seperti memberikan kepuasan kerja serta meningkatkan komitmen organisasi guna meningkatkan pelayanan atau kinerja pada sumber daya manusia untuk rumah sakit. Berdasarkan latar belakang dan mengingat pentingnya kepuasan kerja dan komitmen organisasi di RS PKU Muhammadiyah Bantul, maka tujuan penelitian ini adalah untuk melihat hubungan Komitmen Organisasi Terhadap Kinerja Perawat RS PKU Muhammadiyah Bantul.

Peneliti tertarik mengambil topik tersebut karena peneliti melihat bahwa perawat sebagai sumber daya manusia terpenting dalam rumah sakit dengan jumlah karyawan terbanyak dapat mewakili performa rumah sakit dalam memberikan pelayanan terhadap pasien. Oleh karena itu, pihak manajemen rumah sakit perlu menganalisis tingkat kepuasan kerja dan komitmen perawat dari kecenderungan penurunan indikator tersebut, serta memberikan kebijakan yang 
diperlukan demi meningkatkan semangat kerja para karyawannya. Perawat yang telah memiliki kepuasan kerja yang baik cenderung akan lebih menyukai pekerjaannya dan akan melaksanakan serta menyelesaikan pekerjaannya dengan baik, sedangkan perawat yang telah memiliki tingkat komitmen organisasi yang tinggi cenderung akan senantiasa melakukan pekerjaannya dengan sepenuh hati demi tercapainya tujuan atau nilai dari rumah sakit yang bersangkutan (Ruslan, 2013).

\section{METODE}

Jenis penelitian yang digunakan adalah cross sectional study yaitu suatu rancangan yang mengkaji dinamika korelasi antara variabel independen (komitmen organisasi) dan variabel dependen (kinerja perawat) pada saat bersamaan (point penelitian analitik time approach) (Zainuddin, 2010). Populasi pada penelitian ini adalah seluruh perawat pelaksana RS PKU Muhammadiyah Bantul yang berjumlah 150 perawat. Pengambilan sampel dalam penelitian ini menggunakan sampel total (total sampling) yaitu keseluruhan populasi merangkap sebagai sampel penelitian.

Pengumpulan data primer menggunakan metode triangulasi yaitu pengisian kuesioner oleh responden yang menjadi sampel, observasi responden yang menjadi sampel serta data sekunder. Kuesioner yang digunakan dalam pengumpulan data ini menggunakan modifikasi Organizational Commitment Questionare (OCQ) yaitu skala komitmen afektif, berkelanjutan, dan normative yang dituangkan dalam kuesioner. Tahapan pengolahan data secara umum dalam penelitian kuantittatif melalui tahap Editing (memeriksa), Coding (pemberian identitas), dan Tabulating (pembeberan).

\section{HASIL}

Jumlah responden yang terlibat dalam penelitian sebanyak 150 perawat. Karakteristik responden didapatkan bahwa sebagian besar responden berumur 25 - 35 tahun (45,5\%), berjenis kelamin perempuan (69,7\%), sudah menikah (57,6\%), lulusan SLTA atau sarjana $(39,4 \%)$, menjabat sebagai staf $(66,7 \%)$, dan telah bekerja selama 1-5 tahun (57,6\%). Karakteristik responden cukup homogen 
karena diambil dalam lingkup satu unit pelayanan yang memiliki standar rekrutmen dan profesi yang jelas. Kemampuan responden dalam memahami pernyataan yang diajukan dalam instrumen penelitian diharapkan dapat didukung dari karakteristik umur yang telah dewasa, pendidikan cukup, menjabat sebagai staf. Berdasarkan hasil penelitian diketahui bahwa ada hubungan positif antara iklim organisasi dengan komitmen profesi $(\mathrm{p}=0,001, \mathrm{r}=0,326)$, sehingga hipotesis dalam penelitian ini diterima. Hal ini membuktikan bahwa iklim organisasi dapat berpengaruh terhadap perilaku individu yang berdampak terhadap komitmen profesinya.

Tabel 1. Korelasi Iklim organisasi dengan Komitmen profesi

\begin{tabular}{lc}
\hline \multicolumn{1}{c}{ Koefisiensi Korelasi (r) } & Indeks Analisis \\
\hline Koefisiensi korelasi $(\mathrm{r})$ & 0,326 \\
Koefisien Determinasi $\left(\mathrm{r}^{2}\right)$ & 0,106 \\
$P$ (nilai signifikansi) & 0,001 \\
\hline
\end{tabular}

Kedua variabel tersebut memiliki hubungan yang sedang dan memiliki arah positif $(+)$ dengan kata lain hipotesis pada penelitian ini diterima. Dimana semakin positif Iklim rganisasi maka semakin tinggi komitmen profesi, begitu juga apabila iklim organisasi negatif makan komitmen profesi juga akan rendah. Koefisien determinansi $\left(\mathrm{r}^{2}\right)$ berdasarkan hasil analisa data pada tabel diatas ialah 0,1063 yang berarti sumbangan efektif dari iklim organisasi terhadap komitmen profesi ialah sebesar $10,63 \%$, sedangkan pengaruh faktor lain terhadap komitmen profesi ialah sebesar 89,37\%. Selain itu, nilai signifikansi P didapatkan 0,001 yang lebih kecil dari taraf signifikan 0,05 sehingga dapat disimpulkan bahwa ada hubungan antara iklim organisasi dengan komitmen profesi.

Tabel 2. Perhitungan T-Score Skala Komitmen Profesi

\begin{tabular}{lccr}
\hline \multicolumn{1}{c}{ Kategori } & Interval & Frekuensi & Presentase \\
\hline Tinggi & T-Score $\geq 50$ & 59 & $53,6 \%$ \\
Rendah & T-Score $\leq 50$ & 51 & $46,4 \%$ \\
\hline Total & & 110 & $100 \%$ \\
\hline
\end{tabular}


Berdasarkan tabel 2, diperoleh data yang menunjukkan dari 110 orang subjek yang dijadikan sampel, terdapat 59 orang dengan presentase 53,6\% dikategorikan mempunyai komitmen profesi tinggi, dalam kategori tersebut subjek memiliki pandangan yang positif dan memiliki loyalitas dalam pekerjaannya. Kemudian, terdapat 51 orang dengan presentase 46,4\% dikategorikan memiliki komitmen profesi rendah, dalam kategori tersebut subjek memiliki pandangan yang negatif dan kurang memiliki loyalitas terhadap pekerjaannya.

\section{PEMBAHASAN}

Pemilihan sumberdaya manusia bagi suatu organisasi merupakan hal yang mutlak tetapi sulit dilakukan. Kesulitan tersebut timbul karena setiap individu karyawan memiliki prilaku yang unik dan spesifik dengan kemampuan presepsi yang berbeda-beda, sehingga menghasilkan komitmen yang mempunyai hubungan tingkah laku yang beragam. Sikap karyawan memiliki komitmen organisasi merupakan kemampuan individu yang berbeda - beda dan kemauan menyelaraskan perilakunya dengan kebutuhan, prioritas dan tujuan organisasi dan bertindak untuk tujuan dan kebutuhan organisasi ataupun karyawan tersebut (Sopiah, 2008).

Pengaruh komitmen organisasi terhadap kinerja perawat sebesar 0,579 dan signifikan dan berhubungan positif. Oleh sebab itu, keterlibatan perawat dalam bekerja merupakan derajat sejauh mana seseorang melakukan pekerjaan dan menganggap tingkat kerjanya yang dipresepsikan sebagai penting untuk harga diri perawat dengan tingkat keterlibatan kerja yang tinggi dengan kuat memihak pada jenis kerja dilakukan dan peduli dengan jenis kerja tersebut.

Dalam penelitian ini pengaruh komitmen organisasi terhadap kinerja perwat maupun hasil kerja ternyata hal ini sesuai dengan pendapat bahwa untuk meningkatkan sikap karyawan, pihak perusahan hendaknya meningkatkan disiplin karyawan karna merupakan suatu alat yang digunakan para manajer untuk berkomunikasi dengan karyawan agar mereka bersedia untuk mengubah suatu perilaku atau sikap serta sebagai suatu upaya untuk meningkatkan kesadaran dan kesediaan seseorang menaati suatu peraturan perusahaan dengan norma - norma 
sosial yang berlaku (Rivai, Veithzal; Basri, 2005). Sikap seorang karyawan memegang peranan yang sangat penting, karna sikap tersebut mempengaruhi prilaku hasil kerja seorang perawat (Robbins, Stephen P.; Judge, 2009).

Pengaruh secara simultan (keseluruhan) variabel bebas terhadap variabel terikat (kinerja) di tunjukkan dalam uji $\mathrm{F}$ yang memiliki tingkat signifikansi (probabilitas) sebesar 0,000 < a $(0,05)$ dengan kata lain bahwa variabel komitmen organisasional secara bersama-sama mempunyai hubungan yang positif dan signifikan. Hal ini sesuai dengan pendapat bahwa mereka yang memiliki continuan commitment yang tinggi tetap tinggal karena mereka merasa memerlukannya, sedangkan karyawan memiliki affective commitment yang tinggi tetap tinggal karena mereka menginginkannya dan normative commitment yang tetap tinggal karena mereka merasa seharusnya melakukannya demikian (Panggabean, 2002).

Berdasarkan hasil analisa data menunjukkan bahwa ada hubungan positif antara iklim organisasi dengan komitmen profesi $(p=0,001, r=0,326)$, sehingga hipotesis dalam penelitian ini diterima. Hal ini membuktikan bahwa iklim organisasi dapat berpengaruh terhadap perilaku individu yang berdampak terhadap komitmen profesinya. Dengan demikian hasil penelitian ini menunjukkan bahwa semakin positif iklim organisasi maka semakin tinggi komitmen profesi, begitu juga apabila semakin negatif iklim organisasi maka semakin rendah pula komitmen profesi.

Dalam hal ini, perawat di RS PKU Muhammadiyah Bantul dapat mempersepsikan iklim organisasi dalam lingkungan kerjanya secara positif atau negatif, ketika mereka memberikan persepsi positif terhadap iklim organisasi di rumah sakit tersebut maka mereka akan memiliki komitmen profesi yang tinggi. Begitu pula sebaliknya, ketika mereka memiliki persepsi negatif terhadap iklim organisasi, maka mereka akan memiliki komitmen profesi yang rendah pula. Hal ini didukung oleh penelitian dimana adanya iklim organisasi yang negatif dapat menyebabkan rendahnya komitmen profesi pada individu, dalam penelitiannya dijelaskan bahwa iklim organisasi dapat menjadi faktor negatif untuk komitmen profesi, karena tempat kerja dan 
pemimpin organisasi memiliki pengaruh yang signifikan terhadap kemampuan mempertahankan komitmen profesi (Mazerolle, Eason, \& Pitney, 2015).

Komitmen profesi merupakan keterikatan emosional seseorang dengan profesi, persepsi seseorang mengenai kewajiban dalam profesinya dan manfaat dari menjalankan profesi tersebut. Dimana, ketika seseorang yang memiliki komitmen profesi yang tinggi mereka akan cenderung mempertahankan profesi yang dijalankannya dan bangga dapat menjadi bagian dari profesi tersebut. Perasaan tersebut akan muncul ketika keadaan dalam lingkungan internal organisasi seperti nilai-nilai, peraturan, dan suasana kerja ditangkap dan diserap oleh individu secara positif melalui persepsinya. Iklim organisasi inilah yang dapat mempengaruhi beberapa hal untuk membentuk harapan pegawai dengan konsekuensi yang akan timbul dari beberapa tindakan (Darmawan, 2013).

Penelitian ini hasil $T$-score deskripsi variabel iklim organisasi, subjek yang dikategorikan memiliki persepsi iklim organisasi tinggi lebih banyak dari kategori rendah yaitu 60 orang (56,4\%). Kategori iklim organisasi tinggi tersebut dapat diartikan bahwa subjek mempersepsikan kondisi lingkungan internal di rumah sakit tersebut dengan menyenangkan dan memberikan kenyamanan dalam melakukan pekerjaan. Persepsi kondisi lingkungan internal tersebut muncul karena adanya perlakuan baik dari pimpinan atau atasan dan anggota dari instansi. Dimana, perlakuan tersebutlah yang akan memberikan kenyamanan dan merubah sikap atau perilaku perawat dalam menjalankan profesinya. Perlakuan pimpinan organisasi dan kondisi lingkungan internal dalam organisasi dapat dikatakan memiliki peran penting untuk mengubah perilaku seseorang yang berada dalam organisasi.

Pemimpin dari sebuah organisasi memiliki kemampuan untuk mempengaruhi komitmen profesi seseorang (Mazerolle et al., 2015). Adanya kondisi lingkungan internal yang terbentuk di rumah sakit tersebut, maka dapat mempengaruhi perilaku perawat untuk bertahan dan berkomitmen agar tidak meninggalkan profesinya. Dimana, dari hasil perhitungan $T$ - Socre terdapat 52 orang $(53,6 \%)$ yang dikategorikan memiliki komitmen profesi tinggi. Hal ini 
menyebabkan subjek mempunyai keinginan yang kuat untuk mempertahankan profesi yang Ia jalankan. Keinginan tersebut muncul karena adanya perlakuan baik dalam instansi rumah sakit akan ditangkap sebagai stimulus yang kemudian diinterpretasikan oleh perawat sebagai lingkungan internal yang dapat memberikan kepercayaan untuk mempertahankan, bangga, dan bersungguh-sungguh menjalankan profesinya. Hubungan iklim organisasi dengan komitmen profesi perawat memiliki kekuatan yang relative sedang ( $\mathrm{r}=$ 0,326), begitu pula dengan sumbangan efektif iklim organisasi terhadap komitmen profesi ialah $\left(r^{2}=0,1063\right)$ atau $10,63 \%$ dan sisanya $89,37 \%$. Hal ini menunjukkan bahwa komitmen profesi dipengaruhi oleh banyak faktor selain iklim organisasi. Faktor tersebut ialah komitmen organisasi, jabatan, keinginan sosial, lama bekerja, umur, dan kepuasan pendapatan (Bacharach, S.B; Paula C, Morrow; P.C, 2007).

\section{SIMPULAN}

Berdasarkan hasil analisa dapat disimpulkan bahwa ada hubungan positif antara iklim organisasi dengan komitmen profesi yaitu kinerja perawat. Hal ini ditunjukkan dengan nilai korelasi r sebesar 0,326 dengan taraf signifikan 0,001 $(\mathrm{p}<0,05)$, hal ini berarti semakin positif iklim organisasi disuata layanan kesehatan seperti rumah sakit, maka semakin tinggi komitmen profesi yang dimiliki oleh perawat, begitu pula sebaliknya. Adapun sumbangan efektif dari iklim organisasi terhadap komitmen profesi ialah $\left(r^{2}=0,1063\right)$ atau $10,63 \%$ yang artinya ada 89,7\% faktor lain yang mempengaruhi komitmen profesi seseorang.

\section{UCAPAN TERIMA KASIH}

Ucapan terima kasih kami sampaikan kepada Program Studi Administrasi Rumah Sakit Fakultas Ilmu-ilmu Kesehatan atas bimbingan dan dukungan kepada peneliti.

\section{DAFTAR PUSTAKA}

Azizah, N. (2012). Pengaruh Komitmen Organisasional, Peran Manajer, Dan Partisipasi Penyusunan Anggaran Keuangan Daerah Terhadap Kinerja Manajerial (Studi Kasus Pada Dppkad Kabupaten Sukoharjo). Jurnal Akuntansi.

Bacharach, S.B; Paula C, Morrow; P.C, M. (2007). The theory and measurement of work commitment by Paula C. Morrow (P. C. Morrow, ed.). JAI Press.

Darmawan, D. (2013). Prinsip-Prinsip Perilaku Organisasi. Surabaya: Pena 
Semesta.

Kreitner, Robert; Kinicki, A. (2014). Perilaku Organisasi: Organizational Behavior (9th ed.; Biro Bahasa Alkemis, ed.). Jakarta: Salemba Empat.

Mangkuprawira, S. (2011). Manajemen Sumber Daya Manusia Strategik (2nd ed.). Bogor: Ghalia Indonesia.

Mazerolle, S. M., Eason, C. M., \& Pitney, W. A. (2015). Athletic Trainers' Barriers to Maintaining Professional Commitment in the Collegiate Setting. Journal of Athletic Training, 50(5), 524-531. https://doi.org/10.4085/10626050-50.1.04

Muchlas, M. (2012). Perilaku Organisasi. Yogyakarta: Gajah Mada University Press.

Nawawi, H. (2011). Manajemen Sumber Daya Manusia: Untuk Bisnis yang Kompetitif. Yogyakarta: Gadjah Mada University Press.

Panggabean, M. . (2002). Manajemen Sumber Daya Manusia (Cetakan 1). Jakarta: Penerbit Ghalia Indonesia.

Rivai, Veithzal; Basri, A. F. M. (2005). Performance appraisal: sistem yang tepat untuk menilai kinerja karyawan dan meningkatkan daya saing perusahaan (1st ed.). Jakarta: Rajagrafindo Persada.

Robbins, Stephen P.; Judge, T. A. (2009). Perilaku organisasi = organizational behavior. Jakarta: Salemba Empat.

Ruslan, A. K.; N.; S. C. (2013). The Influence of Organizational Commitment and Individual Competence on Teacher Performance: In the Learning Organization Perspective.(A Study on Elementary School Teachers in Ternate City). International Journal of Business and Behavioral Sciences, 3(8), 19-35.

Sidharta, N., \& Margaretha, M. (2011). Dampak Komitmen Organisasi Dan Kepuasan Kerja Terhadap Turnover Intention: Studi Empiris Pada Karyawan Bagian Operator Di Salah Satu Perusahaan Garment Di Cimahi. Jurnal Manajemen Maranatha, 10(2), 23-45.

Sopiah. (2008). Perilaku Organisasi. Yogyakarta: Andi Offset.

Sunyoto, D. (2011). Prilaku Organisasi. Yogyakarta: CAPS.

Sutrisno, E. (2010). Budaya Organisasi. Jakarta: Kencana.

Yani, M. (2012). Manajemen Sumber Daya Manusia. Jakarta: Mitra Wacana Media.

Zainuddin. (2010). Penelitian Pendekatan Praktis Aplikatif. Bandung: Refika Aditama. 